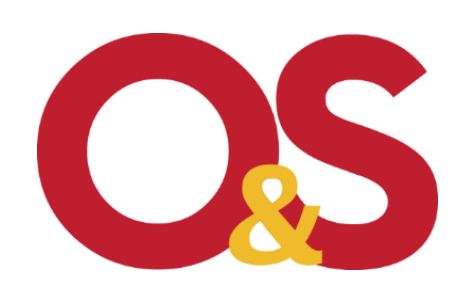

Journal Organizações \& Sociedade2021

28(96), 130-155

(C) Authors 2021

Understanding the Practice of School Management through the Perspective of Sociomateriality

DOI 10.1590/1984-92302021v28n9606EN

ISSN: $1984-9230$

www.revistaoes.ufba.br

NPGA, School of Management

Federal University of Bahia

Received: 02/16/2018

Accepted: 12/05/2019

\author{
Elton Oliveira de Moura ${ }^{a}$ \\ Marcelo de Souza Bispo ${ }^{b}$ \\ a Instituto Federal de Educação, Ciência e Tecnologia de Alagoas, Viçosa, Brazil \\ b Universidade Federal da Paraíba, João Pessoa, Brazil
}

\begin{abstract}
The objective of this study was to analyze the practice of school management in light of sociomateriality in a public school of a capital in the northeast of Brazil. When studying school management from the perspective of sociomateriality, it is understood that this practice does not occur exclusively through the "hands" of the principal, but is a dynamic, situated phenomenon that develops different nuances through the interaction of various actors (human and non-human). A qualitative research method was employed, through shadowing and interview to the double. Data analysis relied on the framework prepared by Bispo (2015). Three fragments of practices that make up the texture of school management were identified: pedagogical practice, administrative support practice, and social interest practice. We found that the practice of school management does not happen in isolation, but is interconnected within the greater texture of sociomaterial practices.
\end{abstract}

Keywords: school management; theories of practice; sociomateriality; education; organizational studies.

\title{
Introduction
}

Education has been receiving considerable attention in management, considering the attempt to introduce managerialist models of school management, which include the discussion of curricula, budget organization and human-resource management (Krawczyk, 2014; Passador \& 
Salvetti, 2013). The changes in the educational process, especially at the beginning of the 20th century, led to the incorporation of a new project of education management whereby education researchers became inspired by standards of efficiency and business productivity (Drabach \& Mousquer, 2009). Seminal Brazilian studies on school management (Leão, 1945; Teixeira, 1961) sought to validate their proposals of school administrative practice by relying on scientific bases developed by pioneers of scientific administration such as Taylor and Fayol (Junquilho, Almeida, \& Silva, 2012). In both the national (Krawczyk, 2014; Passador \& Salvetti, 2013) and international context (Grimaldi \& Serpieri, 2014), however, the field of management and education now manifests tensions about the extent to which school management can and/or should be similar to business management, and whether public policies in education should be guided by pro-neoliberal or pro-social welfare worldviews (Laval, 2019).

Several academics have conducted research on different aspects of school management. In Brazil, there is a predominance of themes such as democratic school management, teaching quality and processes, and management tools in general (Oliveira \& Vasques-Meneses, 2018; Souza, 2006). Hallinger and Kovačević (2019) identified some major themes, such as school effectiveness and performance, as well as leadership as an influential factor for student learning and teacher performance, and finally, cultural changes in school, teachers, and teaching.

Some researchers point out the predominance of binary thinking about school management (Abdian, Nascimento, \& Silva, 2016; Russo, 2004) wherein schools management should focus either on efficiency or on the pedagogical character of the school - both, however, sustain a normative emphasis (Souza, 2006, 2017) toward how school management ought to be and less toward analyzing its current state. Russo (2004) argues that although there is a paradigmatic transition in the literature, the bureaucratic model is still predominant in the practical field of school management.

This article conceives school management beyond the idea of controlling internal variables. Although school management considers aspects of any other administrative practice, it also includes an infinity of singularities that link the school to its normative, social, cultural, and economic environment (Junquilho et al., 2012).

In this article, we assume school management from the perspective of sociomateriality (Leonardi, 2012; Moura \& Bispo, 2020; Orlikowski, 2007). We use the concept of social practice (Gherardi, 2006; Schatzki, Knorr-Cetina, \& von Savigny, 2001) to facilitate the understanding of how sociomaterial relations happen in the (re)production of the social in school management practice. The understanding of school management as a social practice (Gherardi, 2006) draws on the sociomaterial interactions between actors (human and non-human), and avoid dichotomous perspectives such as subject/object, macro/micro, neoliberal/socialist.

This study aims to answer the following question: How to think about an alternative to the predominant functionalist position of school management? The objective of this research was to analyze the practice of school management in the light of sociomateriality in a public school in a capital located in the northeast of Brazil.

Organizational Studies have the potential to contribute to the discussion and solution of major social issues, such as education and school management problems. This approach is important because of the relevance of these themes to society, which suggests that the areas of Management and Organizational Studies cannot be apart from these discussions. We aim to present contributions both in the interlocution between Organizational Studies and Education, as well as to 
present a theoretical perspective that improves the understanding of school management. We believe that practice theories provide a good possibility to create this link. Nicolini (2016) argues that approaches based on the concept of practice are not limited to the understanding of social micro-processes, but also make a significant contribution to the investigation of major social issues. This is because the onto-epistemological orientation of practice theories refutes spatial and temporal classifications like micro and macro, arguing that what differentiates the "size" of a phenomenon is essentially the extension and number of practices that constitute it and not merely its hierarchical or institutional scale.

The concept of social practice opens a possibility for thinking about school management more fluidly and procedurally in regards to its pedagogical, administrative, and societal aspects. In current school management, pedagogical and administrative issues are usually treated as dichotomous elements wherein the societal component is often overlooked.

After this introduction, we present a literature review highlighting some of the main concepts of school management and how it can be understood as a sociomaterial practice. Next, we present our methodological procedures followed by reflections and interpretations upon the data obtained in the field. The final section offers this study's conclusions.

\section{School management}

Education management and school management are key concepts to understand how management works in the promotion of teaching.

Education management refers to activities performed by the different government bodies (municipal, state, and federal) to materialize public policies and national education guidelines (Vieira, 2007). It acts at the level of education systems in the conception of policies and institutional plans, in the design of pedagogical projects, as well as in the implementation, monitoring, and evaluation of teaching activities and the management of financial and material resources (Sander, 2007).

School management is part of education management, and its actions take place in school units with the elaboration and execution of pedagogical proposals, pedagogical support, promotion of integration between school and community, personnel management, management of financial resources, and asset management (Vieira, 2007).

School management began to take shape as a field of academic studies at the beginning of the 20th century. In Brazil, the intensification of this process began in the 1930s, with emphasis on the works developed by Leão (1945) and Teixeira (1961). Drabach and Mousquer (2009) place these authors among the pioneers in theoretical writings about school management in Brazil, having been fundamental for the consolidation of this field of study. However, management and education sometimes have conflicting discussions about whether school management can and/or should be similar to business management, and whether public policies in education should be guided by proneoliberal or pro-social welfare worldviews (Grimaldi \& Serpieri, 2014; Krawczyk, 2014; Laval, 2019; Passador \& Salvetti, 2013).

From the end of the 1970s and beginning of the 1980s, a critical movement began in school management, aiming to offer a better analysis of the work produced in the field while overcoming the prevalent functionalist view. Before this movement, studies often supported rationalfunctionalist conceptions about school management, and these conceptions overshadowed the 
political role of the school in transforming society (Drabach \& Mousquer, 2009). Lück (2017) highlights the paradigmatic evolution of the concept of educational management, in which school management - previously guided by a mechanistic view, influenced by classical management theories - broadens its conception beyond technical aspects and begins to consider the political, pedagogical, and social processes involved in the school context (Drabach \& Mousquer, 2009; Lück, 2017).

In the Brazilian context, school management is considered an integral part of educational management and governed by Law 9,394/96, which establishes the guidelines and bases of national education - known as the Law for Educational Guidelines and Bases (Lei de Diretrizes e Bases - LDB). School management is understood as a mechanism that aims to ensure democratic attributes, guaranteeing quality and effectiveness through the participation of all members of the school community, including teachers, students, administrative staff, parents, and representatives of civil society (Brasil, 1996; Lück, 2017; Vargas \& Junquilho, 2013).

Democratic school management is associated with the establishment of institutional mechanisms that encourage social participation. School management is not restricted only to the action of the school principal (Lück, 2017). Despite holding formal authority, these key figures must build their school-management modus operandi on a daily basis, relying on a democratic perspective, together with all of those who enable and facilitate the school-management process (Lück, 2017; Paro, 2010; Vargas \& Junquilho, 2013).

Vargas and Junquilho (2013) argue that democratic management in public schools (early childhood education, elementary and high school) makes use of several instruments: (a) elections for the position of school principal; (b) school councils composed of parents, students, teachers, public servants, residents, and the school principal; (c) student committees, as a political representation of students; (d) promotion of the administrative, financial, and pedagogical autonomy of the school. The authors also point out that democratic management leads to paradoxical situations in public schools, due to the daily difficulties regarding social relations among the agents that constitute the school's community. Decision-making, for example, consists of complex actions that become susceptible to tension and conflicts of interest, which can lead to management practices that are centralized in the figure of the school principal.

Despite the existence of critical studies in education management and school management, a functionalist view of education management is still predominant in this field of studies, with a direct impact over school management. Several authors (Landri, 2014; Ozga, 2017; Passador \& Salvetti, 2013) have drawn attention to the risks of thinking about education management from this perspective.

This functionalist perspective emphasizes the search for financial control, transparency, and accountability, which are measured through performance indicators (Gorur, 2018). However, the excessive attention to managerial results while drawing on performance indicators has generated debates about the accuracy and adequate use of these numbers (Gorur, 2018; Ozga, 2017). The impact of this managerial perspective on the school community (Gorur, 2018) risks relegating to a lesser position the tacit aspects of teaching-learning that are difficult to measure, marginalizing knowledge circuits that are not directed towards measurable standards of performance (Landri, 2014). 


\section{School management as a social practice}

In our investigation of school management, an alternative stance on the term "management" needs to be explored, extrapolating the barriers of the narrow conventional definition according to which managing is synonymous with controlling resources, especially internal ones (Paula, 2016). Silva (2007) argues that although school management considers aspects common to several other administrative practices, it also emerges from a specific context characterized by "an infinity of peculiarities inherent in its educational, popular and participatory nature" (p. 24, our translation). We seek to discuss an alternative perspective to the functionalist hegemonic view that is present in management, opening up space for an approach that emphasizes the dynamism and complexities present in the daily life of organizations, which emerge from actions that have been socially constructed in relationships between human and non-human actors (Latour, 2005). Thus, this study proposes an understanding of school management through the lens of practice theories (Bispo, 2015; Gherardi, 2006).

For Feldman and Orlikowski (2011), the underlying idea of "practice lenses" is the notion of social life as a continuous and emerging production of actions by various interconnected agents. For them, the practice lens consists of a specific approach to understanding the world, enabling organizational researchers to deal with the complex, dynamic, mobile, and transitory character of contemporary organizations.

It is possible to find several definitions of social practice in the existing literature, suggesting that there is no single theory of practice, but rather a series of theories of practice (Antonacopoulou, 2015; Gherardi, 2017). We adopted the concept of practice present in Gherardi's (2006) writings, which assumes practice as "a mode, relatively stable in time and socially recognized, of ordering heterogeneous items into a coherent set" (p. 34).

Management as a social practice is understood as a continuous process of articulation of complex and diverse practices that arise and transform themselves dynamically (Reed, 1984). In this sense, management approaches are multiple and there is no single way of doing. For this reason, Junquilho (2001) argues that it is not possible to separate management from its daily context; moreover, management as a practice can only be analyzed considering the institutional, organizational, and behavioral perspectives as integral parts of doing management. School management, in this sense, is understood as an emergent and continuous process, produced by the interactions that take place in everyday school life (Poubel \& Junquilho, 2019).

Gherardi (2006) introduces the concept of texture to explain the field of practice. For her, practices emerge in a texture that connects different practices with each other. This texture is held together by the compounding of a certain number of practices that anchor each other. The concept of texture can be used (Gherardi, 2006) to understand the link between the hybrid elements (human and non-human) that relationally weave management in the school context. For Gherardi, "The texture of organizing can be conceived as an imaginary territory, a circumscribed domain marked out by a plurality of organizational actors which comprises ideas, projects, emotions" (p. 49) that are part of what is known as organizational behavior. Bispo (2011) points out that when we refer to the concept of organizational texture (or a texture of practices) as an imaginary territory, we are referring to a metaphorical sphere in order to understand how social practices are enacted, interlacing to form the social sphere. 
The predominant views in management and organization studies focus on understanding these phenomena in regards to their formal and static aspects (Santos \& Silveira, 2015). Adopting the assumptions of practice theories to study public school management allows for the adoption of an alternative view to traditional functionalism. Moreover, the focus on practice leads us to understand school management as a socially constructed texture (Gherardi, 2006) that takes place in a plural context, full of uncertainties, much like the public school, for example. School management in this context can be understood as the interweaving of various actors (principals, teachers, students, administrative staff, community, classrooms, books, etc.), characterizing itself as a form of social doing.

\section{Sociomateriality}

Sociomateriality assumes its social aspect as a result of the interaction between humans and non-humans, which dynamically modify one another (Fenwick, Edwards, \& Sawchuk, 2011). Orlikowski (2007) argues that organizational studies have "overlooked the ways in which organizing is bound up with the material forms and spaces through which humans act and interact" (p. 1435). For Fenwick et al. (2011), humans should not be understood as holders of a privileged status in the world, but as inhabitants of the Earth among other, non-human entities. This debate has been part of the agenda of several researchers (Fenwick \& Landri, 2012; Leonardi, 2012; Orlikowski, 2007) who have sought to understand social phenomena as a result of the interaction between humans and non-humans. Fundamentally, they draw on the assumptions of the post-humanist approach, highlighting material entities as a relevant analytical component in the production of the social.

But why focus on the material? Fenwick (2010) presents some reflections regarding this question: (a) everyday life is wholly involved with material elements (vehicles, architectural constructions, technologies, roads and so on) that are not recognized as relevant due to the excessive focus on human activity; (b) the focus on the sociomaterial can help to reveal the inner dynamics of everyday life; and (c) the sociomaterial perspective enables the reorganization of conventional categories that have become problematic (e.g., formal and informal learning). The perspective of sociomateriality is premised on the idea that social and material aspects of organizations do not have precise inherent meanings, but should be seen as components of an inseparable or indissoluble reality that are perceived in practice (Orlikowski, 2007).

For Orlikowski (2007), "there is no social that is not also material, and no material that is not also social" (p. 1437). This entails that: (a) "all materiality (as defined in the prior section) is social in that it was created through social processes and it is interpreted and used in social contexts" and (b) "that all social action is possible because of some materiality" (Leonardi, 2012, p. 32).

Although the concept of sociomateriality is strongly associated with studies in the area of Science and Technology (Leonardi, 2012; Scott \& Orlikowski, 2017), in this article we treat sociomateriality as a concept that is also present in other approaches. Several theoretical approaches can be considered sociomaterial (Fenwick et al., 2011; Moura \& Bispo, 2020), such as new materialities (Coole \& Frost, 2010), cultural-historical activity theory (Engeström, 2001), complexity theory (Morin, 2005), organizational aesthetics (Strati, 2007), actor-network theory (Latour, 2005), among others.

It is important to notice that material elements emphasized in a sociomaterial analysis vary according to the theoretical perspective adopted, such as technological elements, spaces, symbols, 
and emotions, among others. What these approaches share is the notion that the social is made up of the interactions between human and non-human elements and that non-humans have a capacity for agency, to a greater or lesser extent according to the specifics of each approach.

\section{Methodological procedures}

This research used a qualitative approach supported by a practice-based perspective (Gherardi, 2006) to understand school management as a situated phenomenon on the basis of the interaction between various human and non-human actors, including the researchers themselves. The research was conducted in a public school of the state primary education network located in a peripheral neighborhood of a capital in the northeast of Brazil. The school has been present in the region for over 30 years. It serves about 1,100 students divided into three periods and distributed across grades ranging from Elementary School to High School. Its 68 employees include teachers, auxiliaries, and administrative staff.

The school's principal agreed to participate and signed a free and informed consent form for the development of the research (in accordance with Brazilian research-ethics procedures). Data collection was carried out from July to December of 2015 with approximately 140 hours of observations in the field, primarily in the school. We carried out some other observations in events, meetings, and seminars outside the school. Access to the field was not consistent in terms of days of the week and hours, as well as length of stay, and visits varied from two to five times a week and from two to eight hours a day. This strategy sought to gauge the natural behavior of the people involved and avoid abnormal situations prompted by the researchers' presence. The methods employed in the field shadowing (Czarniawska, 2008) and interview to the double (ITTD) (Nicolini, 2009a), based on a strategy of zooming in and zooming out (Nicolini, 2009b).

Shadowing was used as a data collection strategy for monitoring school management practices and their actors. In this method, the researcher follows a practice (school management) and its actors (human and non-human) as a kind of shadow to capture the practical aspects that result from the interaction between these actors. The main shadowed actors were the school's principal and the school's vice-principal, because they were key figures in the development of the investigated activities. However, other actors, such as teachers, students, and administrative staff, were also shadowed. It is important to note that the use of shadowing was not restricted to the investigation of human action; the non-human elements that composed the researched practices were also observed since they have an essential role in the practices' materiality (Bruni, 2005).

It is important to note that our shadowing procedure involved alternating between moments of proximity and distance, which corresponded to zooming in and zooming out (Nicolini, 2009b, 2009c), respectively. To this end, strategies presented by Nicolini (2009c) were used to guide the researchers in conducting proximal or distanced analyses. Zooming in movements were performed by observing of the actors' interactions, their sayings and doings, the locality's norms, rules, and institutional aspects, and the non-human elements that materialized these practices. Zooming out, meanwhile, was conducted through an analysis of intermediate agents, also attempting to analyze the environment's specific practical relationships in their connection with other social practices. These metaphorical movements provided the researchers both with a deeper understanding of the details and intricacies of the investigated practice (zooming in) and a broader perception (zooming out) of how the analyzed practice related to other practices, forming a texture of practices. Thus, it 
was possible for the researchers to analyze the field's practices by experiencing them and outside the field by reflecting upon them.

Field visits were recorded on a laptop and a mobile phone equipped with a recorder and a camera. Observational data and informal conversations were recorded as soon as possible (during or after the visits) in a field-notes diary. Field notes entries were always typed in an electronic document on the same day or the day after the visit. This strategy aimed to organize the material collected and provide the researchers with moments of reflection on the events that stood out during the field visit. The images and recordings were captured using the mobile phone. This tool was chosen because it drew the least attention from the research participants and ensured more natural interactions. The actors were aware that they were in a research situation, since data collection was authorized directly by the participants through the informed consent form.

The ITTD technique consists of asking respondents to report their activities as if the researchers were going to replace them in their roles. This technique was carried out with three members of the school (principal, vice-principal and a member of the administrative staff) in November 2015, after the initial shadowing period. The objective of the ITTD was to better understand how the interviewed actors carried out their daily activities by asking questions that were formulated during the shadowing period. This specific order of technique application was chosen to complement the observational data; at this stage, we were already familiar with the identified practices and with the actors, which was helpful during our interaction with the interviewees.

Besides images and recordings, other documents linked to the actors' activities were used as data sources. Other data sources were materials collected on the Internet, such as information from the school's Facebook social network page, e-mails, and conversations in WhatsApp (with the school's principal permission). These data sources were important for creating a representation of the various forms of interaction that exist between the actors involved in the school's management, as well as the role of non-humans in this practice. The guidelines proposed by Bispo's (2015) framework were used for data analysis. The framework focuses on identifying activities that link together to form social practices. These practices should be analyzed at a later stage, in light of the initially proposed research objective (see Bispo).

The first data-analysis step entailed a review of all the information collected throughout the research. This included field notes, notes from informal conversations, recordings, photographs and images, as well as reflections formulated during the process of accessing the data. Although the data-collection process is only complete at the end of the field period, analysis began in our first days in the field. The next step involved processing the data through transcriptions and categorization of the interviews and field notes, as well as the analysis of the captured images. We sought to identify the main set of school-management activities as a texture of sociomaterial practices within that locality.

The following fragments of practices were eventually identified: pedagogical practice, administrative practice, and societal practice. These fragments were analyzed based on the approaches of the following theoretical frameworks: Actor-Network Theory, Science and Technology, and Organizational Aesthetics, based on these key elements: (a) the notion of actors' agency and the heterogeneity of relationships in the (re)production of the social; (b) the notion of social practice as an entanglement built on the basis of the relationship between humans and nonhumans; (c) organizational aesthetic judgments. 
Moreover, to create conditions for the analytical stage and represent the fragments of practices' reciprocal connections and interactions, we employed the concept of a "texture" of practices (Gherardi, 2006), with the purpose of understanding the intertwining of the practices that constitute the school's management as a texture of sociomaterial practices.

\section{School management as a texture of sociomaterial practices}

The central role or social function of a school is to provide access to quality education, student training, and the promotion of learning (Lück, 2009). School management is what makes this process viable and possible, encompassing the various aspects that characterize the school as an organization. However, the development of the educational practice is not restricted to issues of curriculum or elements directly related to student education, but also encompasses the management of other elements that support these educational activities, making it more complex and dynamic than first meets the eye. School management is understood as an intertwining of various human and non-human actors (principals, teachers, students, administrative staff, community, classrooms, books, etc.), characterizing itself as a social doing, that is, school management is socially orchestrated by these different actors.

The research process enabled us to observe the main activities of school management. Although every activity established particular relationships with the others, at certain times many of them seemed to be associated to specific perspectives or dimensions of management. Thus, for a better presentation of the data, we chose to group them as fragments of pedagogical practice, fragments of administrative-support practice, and fragments of societal practice. Figure 1 presents the analytical framework that details this process.

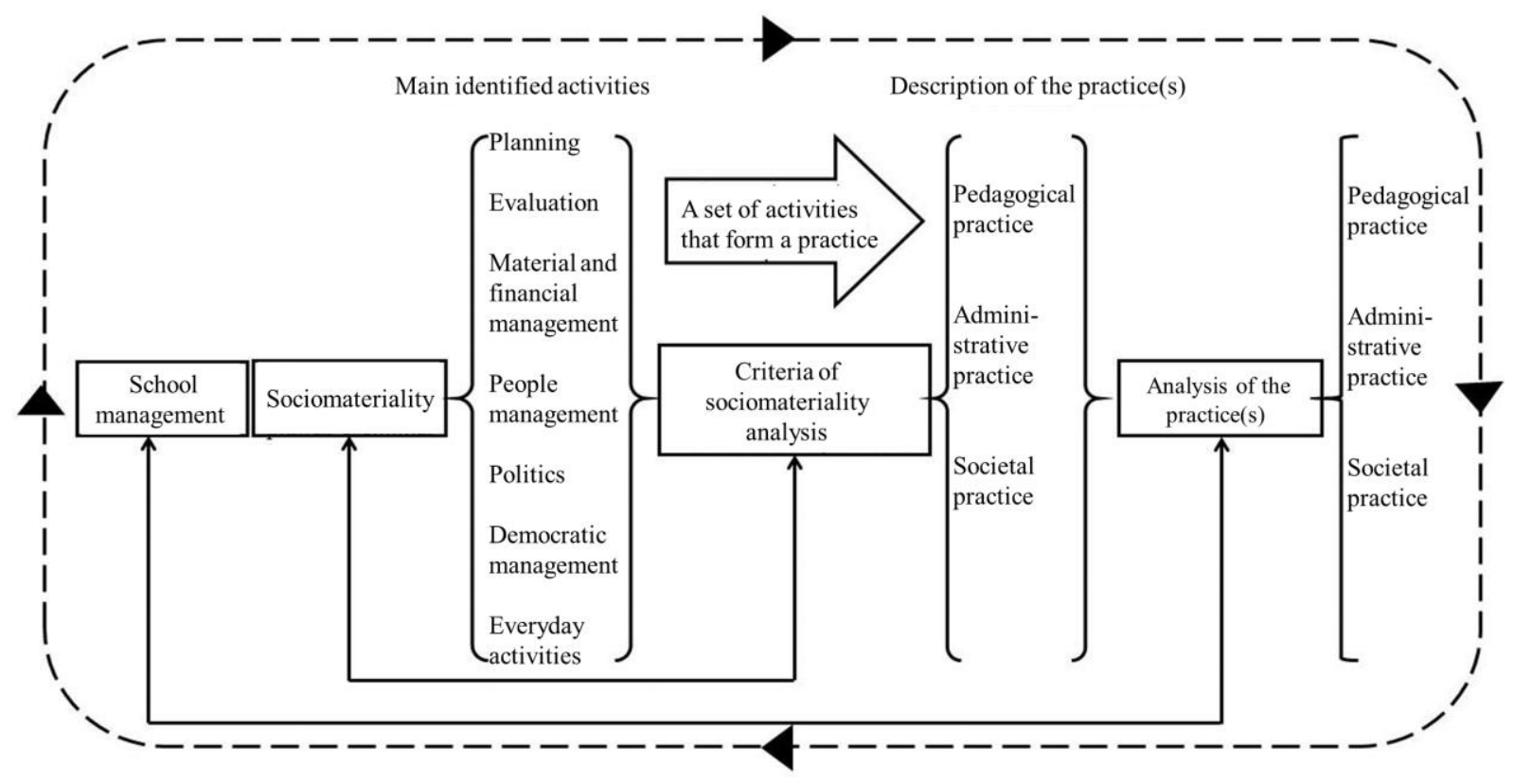

Figure 1. Framework for Data-Analysis Process based on the investigated practices Source: Adapted from Bispo (2015). 
Although they represent a group of activities with the same characteristics, these practice fragments cannot be taken in isolation. One point that should be emphasized is the borderless arrangement (Tureta \& Araújo, 2013) of the school organization and its management, with the interweaving of the practices that form the texture of school management.

The texture of school management is constituted, within this imaginary territory, by practices that happen simultaneously and are in constant interaction with each other, which makes it difficult to rigidly delimit its borders (Gherardi, 2006; Orlikowski, 2007).

Additionally, the term fragments portrays the data collected during the study, since it would be exaggerated to state that the results presented here fully capture the phenomenon under investigation. Thus, through the concept of texture, we sought to understand school management not as the sum of isolated dimensions, but as the intertwining of practice fragments that are related to each other and that, together, characterize school management as a texture of sociomaterial practices.

\section{Fragments of pedagogical practice}

Lück (2009) argues that the main (but not the only) objective of the school as a social organization is the formation (in the sense put forward by Walker, Golde, Jones, Bueschel, \& Hutchings, 2008) of students, which is ensured by the promotion of learning and quality in education. In our case, the set of activities that form the pedagogical practice in school management consists of actions dedicated to ensuring this primary objective. These activities revolve around planning, monitoring, and assessment of pedagogical activities, as well as monitoring the performance of teachers and students.

As far as planning activities are concerned, the school management strongly emphasized the PPP (Pedagogical-Political Project). A PPP with the face of the school should be the fruit of the actions, objectives, and values shared by the actors that form the school community. Furthermore, this document materializes a social process of interaction between human actors (parents, teachers, students, principals, employees, community representatives) and non-human actors (democratic principles, Educational Guidelines and Bases Law (LDB), instruments of participation) (Leonardi, 2012). We were able to ascertain that despite the existence of a democratic discourse on the construction of the PPP, the actual responsibility for the development of the document is heavily concentrated on school principals and teachers. The other members of the school community limited their contribution to being present at the assemblies that voted on the proposed actions. A possible justification for this was raised in the meeting that aimed to discuss the proposal of the new Common National Curricular Base, meant to be discussed together with the entire school community. However, the principal argued that this would be unfeasible: "which father or student would be able to grasp this discussion?" (field notes, December, 2015).

For the PPP and other democratic management mechanisms to be seen as elements that materialize the result of social interactions at school and not just as mere institutional obligations, the elaboration process should include strategies that give voice to all actors in the school community. It is the role of the school principal to conduct this process so that everyone can evaluate and propose improvements or new directions for the school. In the studied school, the participation of parents and community representatives is minimal. In this sense, the relationship between these actors and the school must to be carried out not only in a spirit of accountability e.g. passing on reports or complaining about children's lack of discipline - but also in a spirit of open 
exchange, so that the school community feels like a part of this process. It is important to use an intelligible, clear and straightforward language (Schatzki, 2001) to encourage the participation of all members of the school community.

Besides planning actions, the pedagogical practice is also concerned with the management of educational results (education quality indices), which are also considered in the construction of the PPP. Exams and assessment indices, both at the national level (National High School Examination - ENEM, Basic Education Development Index - IDEB) and at the state level (Education Development Index of Paraíba - IDEPB) function as a mechanism for monitoring the quality of school education. The bodies that shape educational management (Regional Education Management and State Department of Education) confer great importance to these indices. Moreover, excellent performance in these exams directly influences the perception of the quality of teaching and of the school, defining what good management actually means.

The purpose of this discussion is not to condemn the use of measurement mechanisms aimed at the quality of education, but to condemn evaluating management as good or bad only by means of distanced and severely limited indicators. Moreover, education is constituted by multiple interactions and goes through several visible, opaque, or even invisible relationships (Fenwick et al., 2011). School management is a reflection of the complexity and uncertainty of this context, which makes it difficult to measure its quality by standardized grades or scales. This context of complexity and uncertainty was evident in the studied school. Aspects such as classes with too many students (mainly in elementary school), students' socioeconomic profile ranging, which ranged from low to very low income, poor physical structure, indiscipline, violence, drugs, conflicts of interest between employees, little participation by parents, among other aspects, reveal the challenges of the school management in this context (field notes, August 2015).

One of the teachers reported his perspective on the impact of management by means of indices and on the demands of educational management bodies:

A positive result in an assessment like this; it's stimulating, right? It's stimulating for the student . . . because then, at last, the student begins to feel confident ... the teachers begin to realize that their work is producing results, right? And that turns into positive propaganda for the school ... and positive propaganda is all that the department of education wants to hear... sometimes they haven't done anything to improve things here, but then it goes well for them there....

A negative result . . . is discouraging for the student. It is the teacher asking, 'where did it go wrong?' . . . and the school feels it, the Department of Education begins to pressure the principal and vice-principal: "so, what can you do to improve?" . . then you know what happens next, right? The pressure on them falls on us, and the pressure on us falls on the student [laughs]. (Teacher 1, 2015)

The top-down character of education management in this context is evident. The principals are pressured by the controlling bodies, and this pressure is transferred to the teachers and students. This model is detrimental to school management because it deprioritizes the development of the knowledge and citizenship of students as well as the specific demands of the community, giving way to a bottom-up management model meant to show results or providing accountability to controlling bodies. On the other hand, when thinking of school management as a situated 
practice, Gherardi (2006) highlights the deficiencies of the traditional school management style. Traditional school management is considered as a mere part of a larger passive structure of demands and as the reproduction of norms and guidelines, suggesting that the school should instrad be seen within a macrosocial context that properly takes into account its normative, social, economic, and cultural environment (Junquilho et al., 2012).

Another pedagogical aspect of school management is teacher follow-up, in the sense of monitoring and offering support to student performance and teaching activities. The vice-principal expressed difficulties with monitoring the academic performance of teachers. According to her, the lack of technical staff (pedagogue, supervisor, and pedagogical coordinator) to perform this function means that the responsibility falls entirely on principals. This situation makes it difficult to monitor teachers. This perception again points to a bureaucratic form of management that proceeds in blatant disregard for its own context: there are two pedagogues in the school who work exclusively with a tiny number of students with special needs; they could easily take on the task of teacher follow-up since they have a significant amount of idle time in their hands.

Also, some aspects can be highlighted to explain teachers' discouragement and sometimes lack of commitment to their tasks. The lack of motivation to innovate in teaching practice, the lack of continuous training, and frustration with working conditions emerged in some interviews. Some excerpts highlight these challenges inherent to the teaching practice in the studied context:

I've been dedicating myself to work here [at the school] for three years ... but l've came to the point of working in two schools at once ... and it is a horrible experience ... there are many teachers here who teach both here [at the state school] and there [at the municipal school], or they teach here and at private schools to supplement [their income] ... I find it too complicated for someone to be dedicated to two institutions . . . and then what happens to your time for productive leisure?, for you to read, for you to reflect upon your own practice, for you to plan your own actions?

We don't have the necessary infrastructure ... if we need to play a video ... sometimes the TV is broken, sometimes there's a cable missing, sometimes it's a remote that's out of batteries, you know ... you need to take the students for a field trip ... you have to find a way to do it yourself . . . sometimes the school doesn't have a machine to make copies of the exam, and you have to take it out of your own pocket ... so, you see ....

I never imagined that I would get into a fight in the classroom where chairs would 'fly' . . . that's something you don't learn in university. (Teacher 1, 2015)

These talks allowed us to perceive how some non-human actors - like remuneration and work structure - exercise agency (Latour, 2005) in teaching practice, limiting the exercise of the profession and putting important aspects of teaching activity at stake.

The described pedagogical fragments are part of the school management practice, connecting themselves with aspects of the school's social function in order to offer quality teaching to students, as well as guiding the actions of the school community to promote student learning and training. 


\section{Fragments of administrative practice}

The fragments of the administrative practice involve activities that require direct control, such as the management of financial and material resources. These activities demand decision making regarding people (student indiscipline, people management, demands from parents), as well as actions that are considered bureaucratic (organization of school records and documentation). These attributes have the most impact on school principals during their work. Tasks such as preparing accountability reports, pricing surveys, selection of suppliers, purchase management, among other activities that belong to the administrative sphere are usually out of school principals' comfort zones, since in most cases these activities were not part of their initial training as pedagogues.

Although teaching and learning are the purposes of a school, a good infrastructure is necessary (paper, cleaning material, hygienic material, lunch, among others) for educational activities to take place. School activities are only possible through the support of these material elements. Regarding the management of material and financial resources, the leading programs that finance the school operation are the PDDE (Direct Money in School Program) and the PNAE (National School Feeding Plan). The PDDE is intended mainly for expenses with funding (maintenance of the school) and capital (acquisition of assets). The PNAE is responsible for providing funds designed for feeding the students. All funds are transferred directly to the school. The school manages these resources along with the school council. However, some problems are reported by the principal regarding the provision of resources that directly influence the management of the school: (a) delay in providing the funds (b) insufficiency of resources; and (c) limited autonomy in the application of resources.

The delay or lack of financial resources (non-human element) has a direct impact on school management and functioning. In the absence of resources, the alternative is to request the intervention of the state department of education by means of official letters. "Send an official letter, but to receive an answer, that's the difficult part. . but we do send these official letters, right?" said the principal (2015). According to the latter, official letters are sent even though there is a high chance of no solution being provided because the school needs to safeguard against eventual complaints from the state managerial body. As a non-human element (which is sometimes delivered in person and other times by e-mail), the letter functions as a kind of proof that the resources were indeed requested and that the school management sought to solve the problem through the proper bureaucratic channel.

During one of the field visits, the principal was concerned about some students who were taking pictures of the women's restroom, which was in precarious conditions, to share on the social network Facebook as an act of protest. However, according to the principal, several requests and official letters had already been sent to the Regional Education Management (GRE) reporting the problem. After contacting the GRE and reporting the student's intentions, a specialized team from the GRE was immediately addressed for restroom maintenance (field notes, September 2015). It is noticeable that in this situation, the agency of the non-human technological element (Bruni, 2005) Facebook had more impact than the principal's persistent requests. This draws attention to how the practice of school management connects with the practice of political management. In this case, the use of Facebook as a form of resistance would have quickly spread the students' complaints, 
and that would have led to media backlash and to demands and questions from the population about the State's responsibilities.

Regarding insufficient resources, the principal says:

The funding for lunch is allocated according to the [school] census of the previous year. . . last year we had 800 students, this year we have $1170 .$. but we have to give food to a thousand with the money for eight hundred, get it? And [the money] is thirty cents per student ... cents! (School principal, 2015)

During the shadowing period, the school principal spoke about the delay in the payment of the PDDE financial resource: "we're still with what's left of the first portion of 2014. . 2014, see? We still didn't get the 2015 portion, see?" With this delay, the school is unable to carry out certain actions (purchase of office supplies, cleaning supplies, hygienic supplies, minor maintenances) due to lack of resources (field notes, September 2015).

The influence of numbers on the management of a school is once again evident. The number of enrolled students determines the amount of money it will be allocated in the following year. The more students the school has, the more resources it gets. However, if there is a considerable increase from one year to the next, the school may have difficulties with the management of its resources, as in the case reported in the principal's statement above. Besides delays and insufficient funds, the school management argues that there is little flexibility in the utilization of resources. Of the received resources, $80 \%$ must be destined to expenses (maintenance of the school) and $20 \%$ to capital (acquisition of assets). Using these percentages as a baseline, the school community decides how to utilize resources according to the needs of the school.

Paro (2010) argues that the efforts spent to remedy such shortcomings make it difficult to build more participatory and democratic relationships in the school community. The participation of principals and the school community in this process becomes what Silva (2005) calls operative participation. The decisions that are up to them are not political in nature, but merely operational. Decentralization, in this sense, does not affect responsibility or decision-making, but only operational aspects and activities (Silva).

The described administrative-practice fragments enable the connection of school management practices. They entail aspects that support the functioning of the school in terms of adequate structure, adequate control of financial and material resources as well as people management.

\section{Fragments of societal practice}

The practice of management alongside the surrounding community involves several issues and aspects that go beyond the school walls. It highlights how the context of school organization influences the school environment and management.

The daily routine in a democratic school goes beyond pedagogical and administrative practices, having to tackle issues such as violence, drugs, indiscipline, accessibility, parent participation, integration with the community, among other demands. In this sense, it is clear that school management practices have a significant breadth, and that the surroundings have a 
significant influence, demanding different responsibilities from the management according to the school's specific context.

The studied school did indeed reflect its community context. This can primarily be seen in the presence of juvenile offenders, popularly known in the region as "Môfi," who jump over the school walls during classroom hours. The main concern is that the "Môfis" enter the school to use drugs on the court and, in some cases, lure juvenile students to carry out cell phone thefts.

According to the principal, the minors consider the school a space of freedom from police interference. She says that the minors belong to criminal groups that operate in neighboring communities. In particular, the principal mentions a group that calls itself "Okaida" or "OKD" (short form adopted by the group), in reference to the Islamic fundamentalist group Al-Qaeda (field notes, July 2015).

The use of symbols by the group's members is also worthy of note, since they bear a series of values and meanings (Leonardi, Nardi, \& Kallinikos, 2012). In this sense, the underage kids that are members of the Okaida paint their identifications as a way of demarcating the group's territory of action. Figure 2 shows the symbols denoting the presence of the criminal group at the school. In the first image, the doorman tries to negotiate with the minor so as to convince him to leave the school premises. The second and third images show the graffiti made on the school walls.
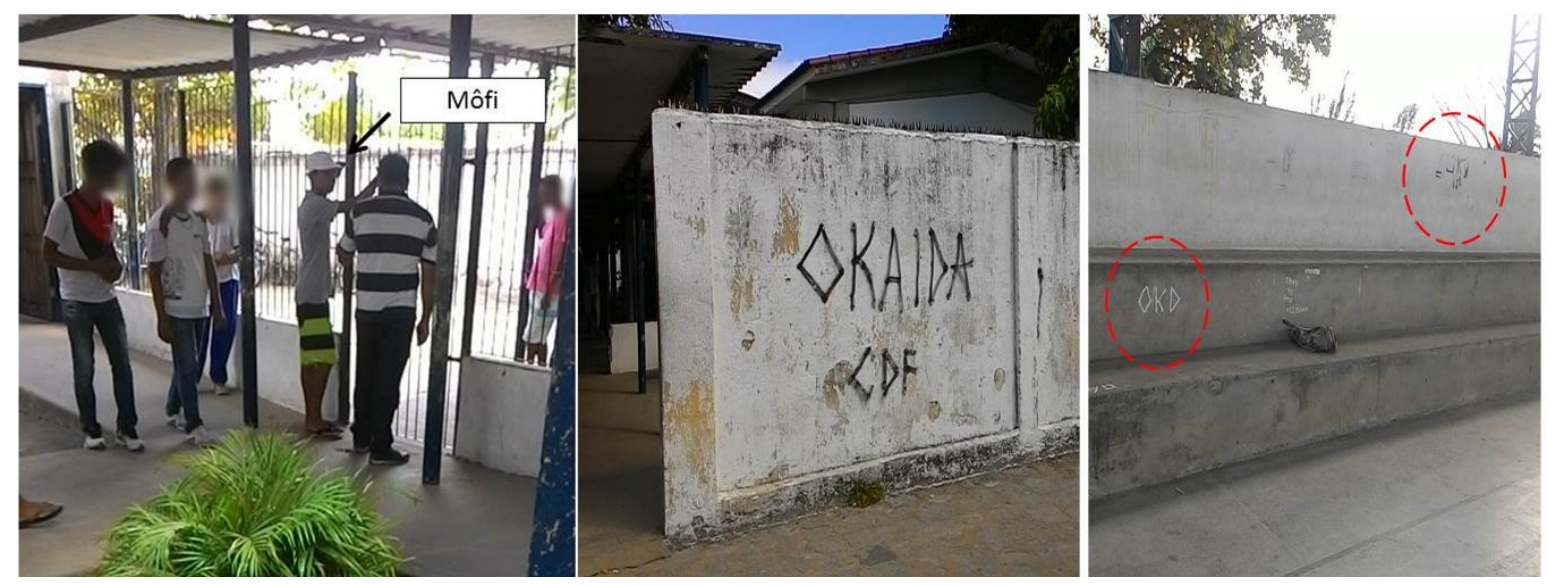

Figure 2. Presence of "môfi" in school; graffiti identifying the criminal group

Source: Elaborated by the authors.

The group is also characterized by the way they dress. Their caps, bracelets, chains, and tattoos are examples of symbols used to represent the group's identity. Tattoos, for example, besides being a way of identifying the person as a member of the group, are also related to the role the individual plays within the group (field notes, July 2015).

The presence of these minors and their practices within the school environment bothers principals, students, and teachers. Some students reported how they feel about the group's presence:

I particularly think it's wrong. . . I feel uncomfortable because the boys use drugs in front of the students. . . marijuana. . . like this. . . it's mostly marijuana . . . we are afraid of being 
robbed, people have been robbed here. . . there are times that we have to carry our cell phones between our legs, like this [pointing] because they keep watching. .. and when we leave the premises, we don't know if we'll bump into them . . . most of them are from this neighborhood. ...

It's very embarrassing, because when we're at break time the break is not actually 'ours'. (Student 2, 2015)

In order to identify these minors or at least prevent them from intermingling with students, the principal requires the use of school uniforms. In this sense, the uniform, besides being a symbol (Leonardi et al., 2012) that identifies the student as such, assumes the function of establishing a contrast in regards to those who do not use it (Strati, 2007); this allows management to take appropriate action against minors who are not students.

Besides the aspects discussed so far, during our research the low level of participation by the school community became quite evident. This has been discussed in the previous sections regarding the construction of the PPP and the action of the school council, but the lack of participation in the PPP's construction on the part of parents and other members of society reveals that the school endures severe problems of social engagement.

The meetings with parents and teachers always take place after the end of each bimester. They are intended to provide a space for parents to talk with teachers about their children's situations. Compared to the number of students enrolled at the school, the meetings had a low number of participants. Additionally, attendance does not reflect the quality of participation (field notes, September 2015).

As a way of making contact with parents or guardians who do not visit the school frequently - and who are often the ones responsible for students with behavioral problems - the vice-principal contacts each of these parents or guardians by phone. Figure 3 presents a notebook that she uses as an organization tool for contacting the parents:

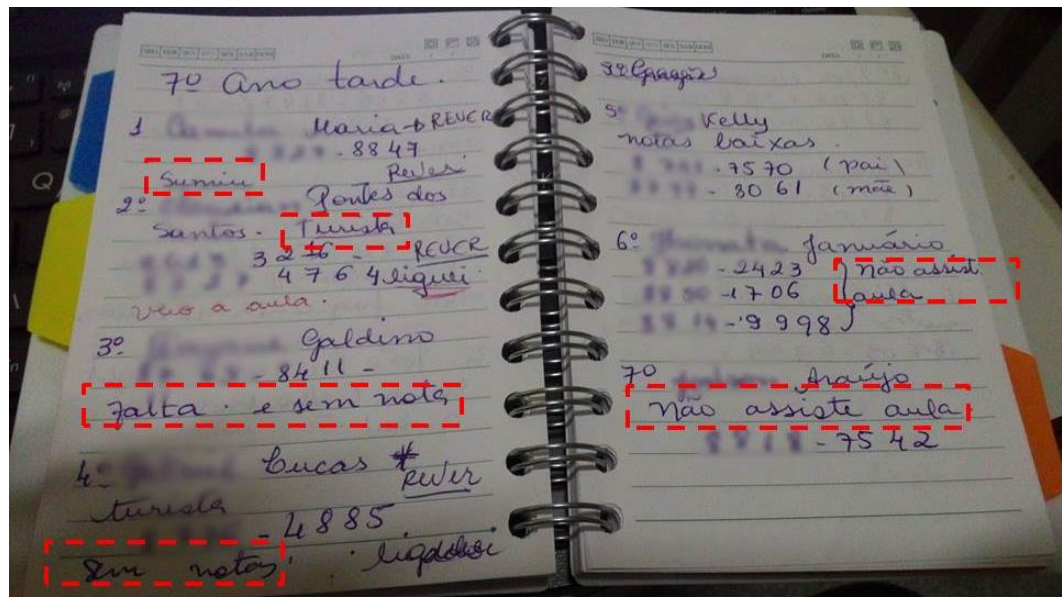

Figure 3. Notebook with information on the class council

Source: Elaborated by the authors. 
Figure 3 contains a list of students made by the teachers after the class council meeting, which is held at the end of each bimester. Parents or guardians of the student can be contacted to alert them of the student's situation and request their presence at school. Each student is assigned a status category regarding their school situation. The most used are: "disappeared," "tourist," "absent and without grades," "without grades," and "does not attend class." The students known by the teachers as "tourists," according to the participants, are those who go to school only for "sightseeing" and do not attend class. The notebook, in this context, is a material vestige of the management's student-monitoring activities. According to the vice-principal, the notebook facilitates the handling of this task (field notes, September 2015).

The process of involving parents or guardians in the activities of the school is still a challenge that requires the establishment of platforms for dialogue to bring the school and the family closer together on the basis of their specific context (Veloso, Craveiro, \& Rufino, 2012). However, it is vital to understand the reality of the parents or guardians, such as: to be aware of their working hours, to promote their participation in the planning of activities, to allow them to give their opinion in the definition of themes, and to encourage moments of evaluation to summarize the discussion. This helps them to present their ideas as well as eventual suggestions, as a way to reaffirm the presence of the family space at school.

The described practice fragments point to the importance of understanding how the school and consequently the school management relate to their surroundings, highlighting what Tureta and Araújo (2013) call the borderless arrangement of organizations. In fact, this practice does not take place in isolation but is connected to other practices, such as public management in the spheres of health, security, and social development.

\section{The interweaving of the school management texture}

During the research, we noted a strong presence of bureaucratic elements involving administrative and pedagogical issues. However, school management cannot occur in a strict normative manner. Our research findings point out that school management, on the contrary, incorporates several nuances that allow it to materialize in the school community in different ways.

The use of the texture metaphor to understand school management practices is mainly intended to make the point that the practice of school management does not take place in separate dimensions (administrative/pedagogical). It also relies on other intertwined activities and practices that happen simultaneously within an imaginary territory. These practices are in constant interaction with each other, which makes it difficult to rigidly delimit their boundaries (Gherardi, 2006; Orlikowski, 2007).

During our observations and especially in the process of data analysis, we were able to ascertain that the political aspect was transversal to the practices that compose school management. Politics is a common element that enables the interlacing of the practices that form the texture of school management. Some underlying aspects that may be highlighted are: (a) the different perceptions of quality (i.e., the definition of what a "good school" would constitute); (b) the management strategies used in the school's routine; and (c) the political element as a background for actions and interactions among actors.

Regarding different perceptions of quality, it is noticeable that the "good school" materializes differently for different actors. The section on the pedagogical-practice fragments 
highlights how the apparent quality of the school is tied to student performance in external evaluation exams (ENEM, IDEB, etc.). In this way, teachers' performance and the quality of management in providing support to teaching do not take into account the school's contextual and daily aspects, such as the teachers' career-path insecurities, infrastructure, and resources.

However, a "good school" as presented by the participants (mainly the students) is one that offers functional conditions - as seen in the students' threat of denunciation regarding the bad conditions of the women's restroom, or even in the insufficiency/delay of resources for food and other school necessities. It also relates to security, as seen in the reports about the presence of juvenile offenders. As Favero and Meier (2013) point out, the school community (parents, teachers, students, etc.) is able to evaluate the quality of the school based on elements that performance indicators are completely blind to.

Regarding strategies adopted in the face of specific school-management challenges, the following are worth emphasizing: (a) the resignification of school uniforms not only as a simple form of identification but as a strategy to expose the minors who access the school for other purposes; and (b) the monitoring of student performance by the school council, because of the low attendance of parents at school meetings, through direct contact by telephone with parents and guardians. These strategies were presented in the section about societal-practice fragments, but they also have a strong connection with administrative and pedagogical support practices, encompassing nonhuman elements as agents in the elaboration and implementation of these strategies.

Furthermore, it was possible to observe that political elements were in the background during most of the interactions between school-management actors. Here, politics is understood as a science whose object is individual and collective well-being. The State is a human necessity because humans are social and political animals by nature (Aristotle, 1998). Humans have a natural need to live together in society. Aristotelian thought on politics is useful in Practice Theories due to proposing a practical philosophy in which knowledge emerges from action, differing from other theories of knowledge such as Plato's, which understands knowledge as emerging from an ideal plane.

Souza (2012) highlights the strong political component of the school space, which is characterized by various disputes and tensions. In the school-management context, politics act as a space of interactions and negotiations between actors, meant to harmonize conflicts. However, a common solution is not always the best solution, considering the diversity of interests present in such a context (controlling bodies, principals, teachers, parents, students); however, in this case common solutions often represent the only possible solutions.

In pedagogical management practice, the political element was evident in activities involving educational examination and the assessment of quantitative indices. The fact that controlling bodies put such a major emphasis on school exam performance generates further demands from school management, influencing the action of teachers and even students themselves. An example is in this fragment of a teacher's commentary: "the pressure on them [principals] falls on us, and the pressure on us falls on the student" (Teacher 1, 2015). Clearly, school management is subject to influences from various elements and entities. In this case, the controlling bodies (State Department of Education and Regional Teaching Management) end up having the most influence over the daily actions of school management.

In the administrative-practice dimension, the political aspect is present primarily in regards to people management. The principals claim to have difficulties with people management, 
especially when it comes to the relationship between staff and service providers. According to the principals, permanent employees can rely on the sense of security provided by a stable employment position, which sometimes causes a certain lack of concern regarding punctuality and frequency. On the other hand, service providers are more concerned with the performance of their activities due to the instability of their positions and the fact that a majority of them have been appointed by politicians. Thus, school management has to manage varying situations stemming from the different interests and influences of external elements (politicians).

Finally, the societal-practice fragments point towards the political aspect of school management as a practice that does not occur in isolation. School management, in this sense, is linked to other, more comprehensive practices, such as security management, social development and healthcare. This characterizes the texture of school management. It has connections with other textures formed by distinct practices, but in the final analysis they are all connected in the intertwining that is social construction.

Figure 4 presents a diagram to represent the texture of school management practices adopted in this work, based on the investigated context.

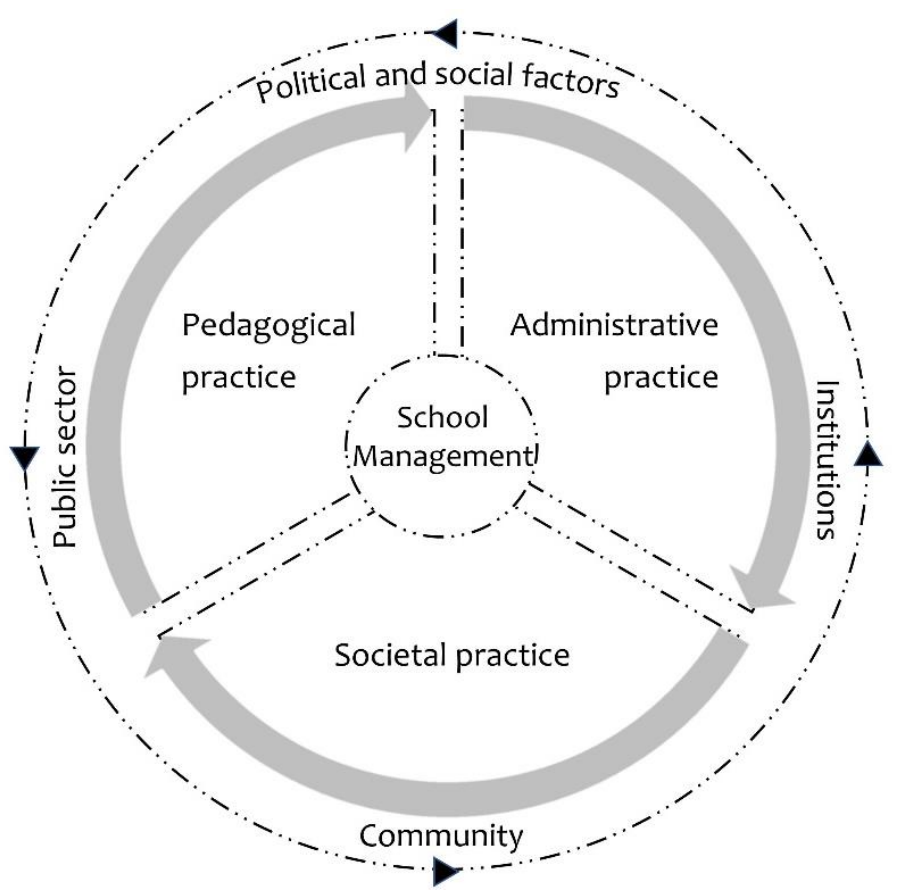

Figure 4. Texture of school management practices

Source: Elaborated by the authors.

Figure 4 represents the overall practice-fragment composition identified during the research, divided into pedagogical practice, administrative practice, and societal practice. It is important to highlight that Figure 4 is the result of a process of abstraction in regards to the studied object and phenomenon. The figure does not aim to define school management as a closed process. We merely aim to provide the reader with an intelligible and materializable representation of the way these practices interrelate in the constitution of a school management practice. 
Through this reflection on the intertwining that forms the texture of school-management practices, our intention was to show that proper school management cannot be easily prescribed. Since it is performed by various actors and involves various interests, emerging from their interactions, school-management practice should not be viewed as a method for obtaining the best solution in absolute terms, but rather as a way to achieve the best solution for the concrete human beings that take part in it and are affected by it.

\section{Conclusions}

The objective of this research was to analyze the practice of school management in light of sociomateriality in a public school located in the northeast of Brazil. It explored how to think of an alternative school management perspective beyond the functionalist position predominant in practice studies. This empirical research revealed that the practice of school management is a dynamic, situated phenomenon that incorporates various nuances while relying on the action of multiple actors (human and non-human) and being deeply affect by the context in which the interaction between them takes place.

In other words, understanding the practice of school management in the light of sociomateriality means to accept a perspective of management that goes beyond prescriptive and strictly rational processes, understanding it as a processual and dynamic phenomenon that is produced, reproduced and modified daily. Through the analysis of the fragments of practice identified during this research, we were able to perceive how non-human elements (physical and non-physical) participate in school-management practices, either as supporting elements, as in the case of material and financial resources, or as mediators in the relationships established between the involved actors.

We believe that this research contributes theoretically to the understanding of school organizations "as they happen" (Schatzki, 2001), showing that their management cannot be based on atomized and dichotomized visions (pedagogical vs. administrative and theoretical vs. practical). Moreover, this research also hopes to foster the understanding of school management as a sociomaterial practice, overcoming myopia regarding the presence of materiality (both in administration and education studies) and the importance of non-human elements as actors that constitute and perform these practices.

Through empirical analysis, we can infer that the practice of school management is continuously (re)shaped by the agency of non-human elements - either in their presence or their absence. In this sense, this study has practical and theoretical implications such as: (a) it is important for both school-management practitioners and scholars to understand that an organization involves the agency of human and non-human actors, so one may take note of possibilities of intervention, change, and improvement; (b) the fact that school management does not take place in isolation, but must be anchored in other practices and entities that forms a texture of practices; and (c) the fact that the quality of school management surpasses the administration of indicators, encompassing other situated aspects inherent in the school's routine.

Moreover, this study contributes to bring areas such as management and organizational studies closer to subjects that are relevant to society, such as school management. A literature review by Oliveira and Vasques-Menezes (2018) regarding scientific production in school management between 2005 and 2015 suggests that researchers in the field of education are the 
predominant developers of these studies. Hallinger and Kovačević (2019) also highlight education journals as mainstream in Education Administration studies. In this sense, we also sought to empirically present the possibility of adopting Practice Theories as an alternative approach for the investigation of significant societal issues.

However, this research has been limited by the great dynamism of actions involving school management and the occurrence of several simultaneous activities; during some moments, we were unable to observe specific actions or other aspects of the practice. For example, while researchers were following female principals in one of their out-of-school activities (meetings, seminars), other types of interactions may have taken place within the school environment, escaping our view.

Since school management represents a field of practice whose study may be carried out through a multiplicity of methods, a few suggestions for future studies are made. First, it would be possible to follow the footsteps of Fenwick et al. (2011) in regards to studies in education. Second, future research could study school management through the lens of different sociomaterial approaches (Complexity Theory, Cultural-Historical Activity Theory, Spatial Theory, Actor-Network Theory), considering their particular contributions. Third, research in this field could adopt sociomateriality as a theoretical approach for the development of research in educational management, analyzing the dynamics of a state or municipal education office, or even the regional management of education. Fourth, future studies could analyze learning processes in the light of a sociological approach to principals and teachers, since most of them do not experience aspects characteristic of professional management during their training, having to eventually learn them in practice.

\section{References}

Abdian, G. Z., Nascimento, P. H. C., \& Silva, N. D. B. (2016). Theoretical-methodological challenges for research on education/school management/administration. Educação \& Sociedade, 37(135), 465-480. doi:10.1590/ES0101-73302016154123

Antonacopoulou, E. P. (2015). One more time: what is practice? Teoria e Prática em Administração, 5(2), 1-26. doi:10.21714/2238-104X2015v5i2-25854

Aristóteles. (1998). A política (2nd ed.). São Paulo, SP: Martins Fontes.

Bispo, M. S. (2011). O processo de aprendizagem coletiva e o uso da tecnologia em agências de viagens: contribuições dos estudos baseados em prática e da etnometodologia (PhD thesis). Universidade Presbiteriana Mackenzie, São Paulo, SP.

Bispo, M. S. (2015). Methodological reflections on practice-based research in organization studies. BAR: Brazilian Administration Review, 12(3), 309-323. doi:10.1590/1807-7692bar2015150026

Brasil. (1996, Dec. 23). Lei n. 9.394, de 20 de dezembro de 1996. Estabelece as diretrizes e bases da educação nacional. Diário Oficial da União, 27833. Retrieved from http://www.planalto.gov.br/ccivil_03/leis/19394.htm

Bruni, A. (2005). Shadowing software and clinical records: on the ethnography of non-humans and heterogeneous contexts. Organization, 12(3), 357-378. doi:10.1177/1350508405051272

Coole, D., \& Frost, S. (2010). Introducing the new materialisms. In D. Coole, \& S. Frost (Eds.), Ontology, agency, and politics (pp. 1-47). Durham: Duke University Press. 
Czarniawska, B. (2008). Organizing: how to study it and how to write about it. Qualitative Research in Organizations and Management, 3(1), 4-20. doi:10.1108/17465640810870364

Drabach, N. P., \& Mousquer, M. E. L. (2009). Dos primeiros escritos sobre administração escolar no brasil aos escritos sobre gestão escolar: mudanças e continuidades. Currículo sem Fronteiras, 9(2), 258-285. Retrieved from https://bit.ly/3dZwvfB

Engeström, Y. (2001). Expansive learning at work: toward an activity theoretical reconceptualization. Journal of Education and Work, 14(1), 133-156. doi:10.1080/13639080020028747

Favero, N., \& Meier, K. J. (2013). Evaluating urban public schools: parents, teachers, and state assessments. Public Administration Review, 73(3), 401-412. doi:10.1111/puar.12022

Feldman, M. S., \& Orlikowski, W. J. (2011). Theorizing practice and practicing theory. Organization Science, 22(5), 1240-1253. doi:10.1287/orsc.1100.0612

Fenwick, T. (2010). Re-thinking the "thing": sociomaterial approaches to understanding and researching learning in work. Journal of Workplace Learning, 22(1/2), 104-116. doi:10.1108/13665621011012898

Fenwick, T., \& Landri, P. (2012). Materialities, textures and pedagogies: socio-material assemblages in education. Pedagogy, Culture \& Society, 20(1), 1-7. doi:10.1080/14681366.2012.649421

Fenwick, T., Edwards, R., \& Sawchuk, P. (2011). Emerging approaches in educational research: tracing the socio-material. London: Routledge.

Gherardi, S. (2006). Organizational knowledge: the texture of workplace learning (Vol. 53). Oxford: Blackwell Publishing.

Gherardi, S. (2017). Sociomateriality in posthuman practice theory. In A. Hui, T. Schatzki, \& E. Shove (Eds.), The nexus of practices: connections, constellations, practitioners (pp. 38-51). New York: Routledge.

Gorur, R. (2018). Escaping numbers? Intimate accounting, informed publics and the uncertain assemblages of authority and non-authority. Science \& Technology Studies, 31(4), 89-108. doi:10.23987/sts.56745

Grimaldi, E., \& Serpieri, R. (2014). Italian education beyond hierarchy: governance, evaluation and headship. Educational Management Administration \& Leadership, 42(4), 119-138. doi:10.1177/1741143213510501

Hallinger, P., \& Kovačević, J. (2019). A bibliometric review of research on educational administration: science mapping the literature, 1960 to 2018. Review of Educational Research, 89(3), 335-369. doi:10.3102/0034654319830380

Junquilho, G. S. (2001). Gestão e ação gerencial nas organizações contemporâneas: para além do "folclore" e o "fato". Gestão \& Produção, 8(3), 304-318. doi:10.1590/S0104$530 \times 2001000300007$

Junquilho, G. S., Almeida, R. A., \& Silva, A. R. L. (2012). As "artes do fazer" gestão na escola pública: uma proposta de estudo. Cadernos EBAPE.BR, 10(2), 329-356. doi:10.1590/s167939512012000200006 
Krawczyk, N. (2014). Ensino médio: empresários dão as cartas na escola pública. Educação \& Sociedade, 35(126), 21-41. doi:10.1590/s0101-73302014000100002

Landri, P. (2014). Governing by standards: the fabrication of austerity in the italian education system. Education Inquiry, 5(1), 24057. doi:10.3402/edui.v5.24057

Latour, B. (2005). Reassembling the social: an introduction to actor network theory. Oxford: Oxford University Press.

Laval, C. (2019). A escola não é uma empresa: o neoliberalismo em ataque ao ensino público. São Paulo, SP: Boitempo.

Leão, A. C. (1945). Introducão à administracao escolar. São Paulo, SP: Companhia Editora Nacional.

Leonardi, P. M. (2012). Materiality, sociomateriality, and socio-technical systems: what do these terms mean? How are they related? Do we need them? In P. M. Leonardi, B. A. Nardi, \& J. Kallinikos (Eds.), Materiality and organizing: social interaction in a technological world (pp. 2548). Oxford: Oxford University Press.

Leonardi, P. M., Nardi, B. A., \& Kallinikos, J. (Eds.). (2012). Materiality and organizing: social interaction in a technological world. Oxford: Oxford University Press.

Lück, H. (2009). Dimensões da gestão escolar e suas competências. Curitiba, PR: Positivo.

Lück, H. (2017). Gestão educacional: uma questão paradigmática. Rio de Janeiro, RJ: Vozes.

Morin, E. (2005). Ciência com consciência (8th ed.). Rio de Janeiro, RJ: Bertrand Brasil.

Moura, E. O., \& Bispo, M. S. (2020). Sociomateriality: theories, methodology, and practice. Canadian Journal of Administrative Sciences, 37(3), 350-365. doi:10.1002/cjas.1548

Nicolini, D. (2009a). Articulating practice through the interview to the double. Management Learning, 40(2), 195-212. doi:10.1177/1350507608101230

Nicolini, D. (2009b). Zooming in and out: studying practices by switching theoretical lenses and trailing connections. Organization Studies, 30(12), 1391-1418. doi:10.1177/0170840609349875

Nicolini, D. (2009c). Zooming in and zooming out: a package of method and theory to. In S. Ybema, D. Yanow, \& H. Wels (Eds.), Organizational ethnography: studying the complexities of everyday life (pp. 120-138). London: Sage.

Nicolini, D. (2016). Is small the only beautiful? Making sense of 'large phenomena' from a practicebased perspective. In A. Hui, T. Schatzki, \& E. Shove (Eds.), The nexus of practices: connections, constellations, practitioners (pp. 98-113). London: Routledge. doi:10.4324/9781315560816

Oliveira, I. C., \& Vasques-Meneses, I. (2018). Revisão de literatura: o conceito de gestão escolar. Cadernos de Pesquisa, 48(169), 876-900. doi:10.1590/198053145341

Orlikowski, W. J. (2007). Sociomaterial practices: exploring technology at work. Organization Studies, 28(9), 1435-1448. doi:10.1177/0170840607081138

Ozga, J. (2017). Education policy should not be driven by performance data. Nature Human Behaviour, 1(1), 14. doi:10.1038/s41562-016-0014

Paro, V. H. (2010). A educação, a política e a administração: reflexões sobre a prática do diretor de escola. Educação e Pesquisa, 36(3), 763-778. doi:10.1590/\$1517-97022010000300008 
Passador, C. S., \& Salvetti, T. S. (2013). Gestão escolar democrática e estudos organizacionais críticos: convergências teóricas. Educação \& Sociedade, 34(123), 477-492. doi:10.1590/S010173302013000200009

Paula, A. P. P. (2016). Em busca de uma ressignificação para o imaginário gerencial: os desafios da criação e da dialogicidade. RAM: Revista de Administração Mackenzie, 17(2), 18-41. doi:10.1590/1678-69712016/administracao.v17n2p18-41

Poubel, L., \& Junquilho, G. S. (2019). Para além do management: o processo de managing em uma escola pública de ensino fundamental no Brasil. Cadernos EBAPE.BR, 17(3), 539-551. doi:10.1590/1679-395173528

Reed, M. I. (1984). Management as a social practice. Journal of Management Studies, 21(3), 273285. doi:10.1111/j.1467-6486.1984.tb00411.x

Russo, M. H. (2004). Escola e paradigmas de gestão. EccoS: Revista Científica, 6(1), 25-42. doi:10.5585/eccos.v6i1.366

Sander, B. (2007). A pesquisa sobre política e gestão da educação no Brasil: uma leitura introdutória sobre sua construção. Revista Brasileira de Política e Administração da Educação, 23(3), 421-447. doi:10.21573/vol23n32007.19141

Santos, L. L. S., \& Silveira, R. A. (2015). Por uma epistemologia das práticas organizacionais: a contribuição de Theodore Schatzki. Organizações \& Sociedade, 22(72), 79-98. doi:10.1590/1984-9230724

Schatzki, T. R. (2001). Introduction: practice theory. In T. R. Schatzki, K. Knorr-Cetina, \& E. von Savigny (Eds.), The practice turn in contemporary theory (pp. 1-14). New York: Routledge.

Schatzki, T. R., Knorr-Cetina, K., \& von Savigny, E. (2001). The practice turn in contemporary theory. New York: Routledge.

Scott, S. V., \& Orlikowski, W. J. (2017). Entanglements in practice: performing anonymity through social media. MIS Quarterly, 38(3), 873-893. doi:10.25300/misq/2014/38.3.11

Silva, J. B. (2007). Um olhar histórico sobre a gestão escolar. Educação em Revista, 8(1), 21-34. doi:10.36311/2236-5192.2007.v8n1.616

Silva, L. C. F. (2005). Estado e políticas de gestão financeira para a escola pública: a autonomia da escola no PDDE (Master thesis). Universidade Federal do Pará, Belém, PA.

Souza, Â. R. (2006). Os caminhos da produção científica sobre gestão escolar no Brasil. Revista Brasileira de Política e Administração da Educação, 22(1), 13-39. doi:10.21573/vol22n12006.18720

Souza, Â. R. (2012). A natureza política da gestão escolar e as disputas pelo poder na escola. Revista Brasileira de Educação, 17(49), 159-174. doi:10.1590/\$1413-24782012000100009

Souza, Â. R. (2017). As teorias da gestão escolar e sua influência nas escolas públicas brasileiras. Revista de Estudios Teóricos y Epistemológicos en Política Educativa, 2, 1-19. doi:10.5212/retepe.v.2.016

Strati, A. (2007). Organização e estética. Rio de Janeiro, RJ: FGV Editora.

Teixeira, A. (1961). Que é administração escolar? Revista Brasileira de Estudos Pedagógicos, 36(84), 84-89. Retrieved from https://bit.ly/3dLiYrN 
Tureta, C., \& Araújo, B. F. V. B. (2013). Escolas de samba: trajetórias, contradições e contribuições para os estudos organizacionais. Organizações \& Sociedade, 20(64), 111-129. doi:10.1590/S1984-92302013000100008

Vargas, R. A. A., \& Junquilho, G. S. (2013). Funções administrativas ou práticas? As "artes do fazer" gestão na escola mirante. Revista de Ciências da Administração, 15(35), 180-195. doi:10.5007/2175-8077.2013v15n35p180

Veloso, L., Craveiro, D., \& Rufino, I. (2012). Participação da comunidade educativa na gestão escolar. Educação e Pesquisa, 38(4), 815-832. doi:10.1590/S1517-97022012005000009

Vieira, S. L. (2007). Políticas e gestão da educação básica: revisitando conceitos simples. Revista Brasileira de Política e Administração da Educação, 23(1), 53-69. doi:10.21573/vol23n12007.19013

Walker, G. E., Golde, C. M., Jones, L., Bueschel, A. C., \& Hutchings, P. (2008). The formation of scholars: rethinking doctoral education for the twenty-first century. San Francisco: Jossey-Bass.

\section{Funding}

This study was financed in part by the Coordination for the Improvement of Higher Education Personnel - Brazil (CAPES) - Finance Code 001. We also acknowledge the National Council for Scientific and Technological Development (CNPq).

\section{Acknowledgements}

The authors acknowledgement the associate editor and the reviewers for the contributions that made it possible to improve the article during the peer review process.

\section{Authorship \\ Elton Oliveira de Moura}

Master in Management at Universidade Federal da Paraíba (UFPB), Brazil. Professor at the Instituto Federal de Educação, Ciência e Tecnologia de Alagoas (IFAL),Brazil.

E-mail: eltonom@gmail.com

ORCID: https://orcid.org/0000-0002-0172-724X

\section{Marcelo de Souza Bispo}

Ph.D. in Management at Universidade Presbiteriana Mackenzie (Brazil). Associate Professor in Management Department at Universidade Federal da Paraíba (Brazil).

E-mail: marcelodesouzabispo@gmail.com

ORCID: https://orcid.org/0000-0002-5817-8907 


\section{Conflict of interests}

The authors have stated that there is no conflict of interest.

\section{Authors' contributions}

First author: conceptualization (equal), formal analysis (equal), investigation (lead), methodology (equal), writing-original draft (lead), writing-review \& editing (equal).

Second author: conceptualization (equal), formal analysis (equal), investigation (supporting), methodology (equal), writing-original draft (supporting), writing-review \& editing (equal).

\section{Plagiarism check}

O\&S submits all documents approved for publication to a plagiarism check, using specific tools.

\section{Data availability}

O\&S encourages data sharing. However, in compliance with ethical principles, it does not demand the disclosure of any means of identifying research participants, fully preserving their privacy. The practice of open data seeks to ensure the transparency of research results, without requiring research participants to disclose their identities.

O\&S is signatory to DORA (The Declaration on Research Assessment) and to COPE (Committee on Publication Ethics). 